\title{
Secondary education reform in the independent Ukraine (1991-2017): concepts, programmes, doctrines and strategies
}

\author{
L. D. Berezivska
}

V.O. Sukhomlynskyi State Scientific and Pedagogical Library of Ukraine, Kyiv, Ukraine

Corresponding author. E-mail: lberezivska@ukr.net_ORCID: 0000-0002-5068-5234

Paper received 25.01.19; Accepted for publication 04.02.19.

\section{https://doi.org/10.31174/SEND-PP2019-187VII76-04}

\begin{abstract}
The article covers the content of the main regulatory documents (concepts, programmes, doctrines, and strategies) regarding secondary education reform in the independent Ukraine $(1991$ - 2017) in order to gain historical and educational knowledge about the mentioned phenomenon and enrich pedagogical source study. The analysed sources reveal the history of the national public education policy, school reforms and counter-reforms, and scientific and pedagogical works by Ukrainian educators. They may be helpful for conducting historical and pedagogical research on the history of secondary education reform in the independent Ukraine.
\end{abstract}

Keywords: secondary education reform, regulatory base, concepts, programmes, doctrines, strategies, pedagogical source study, Ukraine.

Introduction. Reforms and counter-reforms being components of public education policy are implemented in the context of social, political, economic, and pedagogical determinants which influence their strategies. In $1991-2017$ secondary education reform in the independent Ukraine was marked by 'significant achievements and positive tendencies as well as mistakes which keep it back from high quality and integration into the European and world education area' [13, p. 55]. In spite of the low level of realisation of strategic tasks, positive and negative results of reforms and counterreforms, the documents regulating the development of secondary education during the mentioned historical period were among reform achievements. First of all, we should note, Ukrainian educational lawmaking became more active in 1990 - 1991 during the struggle for the independence of Ukraine and renewal of Ukrainian school. Unsolicited education documents (both individual and collective concepts of all-Ukrainian or regional character) mentioned in our previous papers indicate the intensification of the national pedagogical thought regarding the development of the national secondary education being a priority link and an integral part of continuing education [21]. The educators' ideas were the background for official documents (approved on the departmental or state levels) developed under different social, political, and economic conditions vary in structure, but the majority of them contain the following components: structure, purpose, principles of education, management, content of secondary education, types of educational establishments, and ways and conditions of realisation, etc.

During the years of independence the Ministry of Education and Science of Ukraine (the name of the ministry was changed several times) and the National Academy of Educational Sciences of Ukraine (hereinafter referred to as the NAES of Ukraine) developed a lot of official regulatory documents (concepts, programmes, doctrines, and strategies) which defined the development of secondary education in Ukraine.

A brief review of publications on the topic. A historiographical review of literature has showed that the problem of school education reform taken place in 1991 - 2017 was studied by many Ukrainian researchers (L.D. Berezivska, 2012, 2018; N.I. Bidenko, 2009; V.V. Halakh, 2014; H.V. Kasianov, 2015; Y.V. Krasniakov, 2009; V.H. Kremen, 2003; V.I. Luhovyi, Y.O. Molchanova, N.H. Protasova, 2012; O.Y. Savchenko, 2000; O.V. Sukhomlynska, 2010, and others) $[1 ; 21 ; 2 ; 3 ; 5 ; 10 ; 11 ; 18 ; 19 ; 20]$. The development of secondary education in the independent Ukraine was characterised in The National Report on the State and Pro- spects of the Development of Education in Ukraine (2016) edited by the President of the NAES of Ukraine V.H. Kremen. This document defines the main periods of the development of public policy in the field of education in 1991 2016 [13]. At the same time the problem under discussion is not studied enough from the historical and pedagogical point of view.

The purpose of our paper is to analyse the regulatory documents regarding secondary education reform in the independent Ukraine in 1991 - 2017 in order to gain historical and pedagogical knowledge about the mentioned phenomenon and enrich pedagogical source study.

Materials and methods. A set of methods (historiographical analysis, source study approach, synthesis, generalisation, chronological method) was used to analyse periodicals and serials in which regulatory documents and papers regarding the problem were published.

Research findings. The following concepts made the basis for the development of secondary education in the independent Ukraine: The Project of the Concept of Secondary National School of Ukraine, 1990, developed by the Research Institute of Pedagogy of the Ukrainian Soviet Socialist Republic (the Ukrainian SSR) and the Ministry of National Education of the Ukrainian SSR and approved by the ministry board on 12 September 1991; The Conception of Formation of the System of Secondary Education Institutions for the Development of Creative Personality, 1996; The Project of the Twelve-year Secondary Education Concept, 2000, approved by the ministry board on 22 November 2001; The Concept of the State School of the Future Special Purpose Social Programme for 2007 - 2010, approved by the Cabinet of Ministers of Ukraine on 13 April 2007; The New Ukrainian School Concept of Public Policy in the Field of Secondary Education for 2016-2029, 2016, approved by the Cabinet of Ministers of Ukraine, and other documents [8;9;6;7].

The following programmes positively influenced the development of secondary education: The Programme for the Development of Public Education in the Ukrainian SSR for the transition period (1991 - 1995), 1991, and the State National Osvita (Education) Programme (Ukraine of the 21 century), 1993 [17; 4].

The doctrines (The National Doctrine of the Development of Education, 2002, approved by the President of Ukraine) and strategies (The National Strategy of the Development of Education in Ukraine for 2013 - 2021, 2013, approved by the President of Ukraine) defined the backbone ways of secondary education reform $[12 ; 15]$. The scientists working at the NAES of Ukraine played a significant role in the for- 
mation of educational lawmaking, as they developed the mentioned documents [13, p. 27]. Let's characterise the key documents in brief.

The State National Osvita (Education) Programme (Ukraine of the 21 century), 1993, defined the following: strategic tasks, priority lines, main ways of secondary education reform in Ukraine, principles of realisation of the formulated tasks (priority, democratisation, humanisation, national orientation, continuing education, unity of education and upbringing, and variance of education), structure of education (primary, basic secondary, and complete secondary education), types of educational establishments, content of secondary education (methodological principles, academic curriculum, content of subject spheres, invariant and variant components, core education in senior high school), and educating (forms, period of education, evaluation), etc. [4].

The National Doctrine of the Development of Education, 2002, approved by the President of Ukraine, declared the system of concept ideas about the strategy of the development of education, secondary education in particular, at the beginning of the 21 st century. According to this document the national education should become competitive in the European and world education area [12].

The National Strategy of the Development of Education in Ukraine for 2013 - 2021, 2013, outlined the following: the aim (improving access to quality education according to the requirements for the innovative stable social and economic development; personality development taking into consideration one's own individual abilities and needs on the basis of continuing education), and strategic tasks to be fulfilled by public policy in the field of education during 2013 - 2021, in secondary education in particular (education is obligatory for all children and youth taking into account the state standards of secondary education; optimisation of secondary education establishments taking into consideration demographic, economic, and social prospects of regional development and social needs; variety in education models, for rural children in particular; creation of favourable conditions for the development of private schools; renewal of the content, forms, and methods of educational process on the basis of one's own orientation and competence approach; improvement of educational process by means of introducing psychopedagogical scientific advances, educational innovations and ICT; creation of favourable conditions for differentiation in education, improvement of vocational guidance and training, core education, individual educational development taking into account one's own needs, interests, and abilities) [15].

The New Ukrainian School Concept of Public Policy in the Field of Secondary Education for 2016 - 2029, 2016, suggests ideas about the reasons for its development (the need to solve the problem of low secondary education quality in 1992 - 2016), aim (to reform secondary education radically), reform strategies (approval of new state standards for secondary education taking into consideration competences necessary for successful self-realisation; introduction of a new principle of partnership pedagogy, that is cooperation between pupil, his parents and teacher; improvement of teacher's motivation by means of providing him with academic freedom and stimulating to professional development; introduction of the child-centred principle (focus on pupil's needs); improvement of educational process; building of such school structure which will make it possible to get into the new content of education and acquire new competences necessary for successful self-realisation; decentralisation and effective secondary education management; equitable distribution of public money which will positively influence equal access to quality education; creation of advanced educational environment which will provide pupils, teachers, and parents with necessary conditions, means, and techniques; access to education in rural areas or bringing children to school); ways and means to solve the problem of low secondary education quality (to take into account the world best practices, to develop new state standards of secondary education; to reform secondary education pedagogy, to reform the system of secondary education management, to transfer to twelve-year secondary school with three-year core school of academic or vocational orientation, to reform the system of government financing in the field of secondary education) [7]. It should be marked, that The Concept of Secondary School of Ukraine developed by the scientists working at the NAES of Ukraine underlay The New Ukrainian School Concept of Public Policy in the Field of Secondary Education for 2016 2029 [14, p. 2].

Conclusions. The analysis of the mentioned documents indicates the following: creation of a new methodology for the development of the national secondary education in the independent Ukraine; development of a new lawmaking; active participation of scientists, educationalists, research institutions, the National Academy of Educational Scientists of Ukraine in particular, higher and secondary education establishments, public and cultural workers; preparation of documents regulating the development of Ukrainian secondary education on the basis of European values and advanced principles such as national, democratic, humanistic, childcentred, differential, individual, variant, and other principles. 'The progressive reform ideas and approaches still have not been realised in full. There were a lot of mistakes resulted in many problems and drawbacks in school education' [13, p. 55]. But the analysed documents reflect the history of the national public education policy, school reforms and counterreforms, and scientific and pedagogical works by Ukrainian educators, and enrich pedagogical source study. The gained knowledge may be helpful for conducting historical and pedagogical research on the history of secondary education reform in the independent Ukraine. This will be discussed in our further publications.

\section{ЛІТЕРАТУРА}

1. Березівська Л. Д. Шкільна реформа в Україні початку 90-х років XX століття як перехідний період до особистісно орієнтованої парадигми освіти / Лариса Березівська // Педагогічна і психологічна науки України : зб. наук. праць : в 5 т. Київ : Пед. думка, 2012. - Т. 1 : Загальна педагогіка та філософія освіти. - С. 180-190.

2. Біденко Н. Розвиток загальної середньої освіти в Україні в період незалежності / Наталія Біденко // Наук. зап. Серія: Історичні науки / Кіровоград. держ. пед. ун-т ім. Володимира Винниченка. - Кіровоград, 2009. - Вип. 12. - С. 213-225. Бібліогр.: 14 назв.

3. Галах В. В. Специфіка реформування середньої освіти в незалежній Україні / Галах В. В. // Таврійський вісн. освіти. - 2014. - № 4. - С. 274-281. - Бібліогр.: 27 назв.

4. Державна національна програма «Освіта» («Україна XXI століття») : затв. постановою Кабінету Міністрів України від 3 листоп. 1993 р. № 896 // Освіта. - 1993. - Груд. (№ 44/46). C. $2-15$.

5. Касьянов, Г. Освітня система України 1990-2014 : аналіт. огляд. / Георгій Касьянов ; Благодійний фонд «Інститут розвитку освіти» - Київ : ТАКСОН, 2015. - 52 с.

6. Концепція 12-річноїзагальної середньоїосвіти (проект)//Інформ. зб. М-ва освіти і науки України. - 2000. - № 21. - С. 10-31. 
7. Концепція реалізації державної політики у сфері реформування загальної середньої освіти «Нова українська школа» на період до 2029 року [Електронний ресурс] : схвалено розпорядж. Кабінету Міністрів України від 14 груд. 2016 р. № 988-p // Законодавство України / Верхов. Рада України. Текст. дані. - Київ, 2016. - Режим доступу: http://zakon2.rada.gov.ua/laws/show/988-2016-\%D1\%80 (дата звернення: 17.08.2018). - Назва з екрана.

8. Концепція середньої загальноосвітньої національної школи України : проект / М-во нар. освіти УРСР, НДІ педагогіки УРСР // Рад. освіта. - 1990. - 14 серп. (№ 65). - С. 1-3.

9. Концепція становлення мережі середніх закладів освіти для розвитку творчої обдарованості // Інформ. зб. М-ва освіти України. - 1996. - № 17/18. - С. 48-64.

10. Красняков Є. В. Перспективи освітянського законодавства України [Електронний ресурс] / Красняков С. В. // Державне управління: теорія та практика : електрон. наук. фах. вид. / Нац. акад. держ. упр. при Президентові України. - Текст. дані. - Київ, 2009. - № 2. - Бібліогр.: 8 назв. - Режим доступу: http://academy.gov.ua/ej/ej10/doc_pdf/Krasniakov.pdf (дата звернення: 19.12.2018). - Назва з екрана.

11. Кремень В. Г. Освіта і наука України: шляхи модернізації (Факти, роздуми, перспективи). - Київ: Грамота, 2003. - 216 c.

12. Національна доктрина розвитку освіти : затв. указом Президента України від 17 квіт. 2002 р. № 347 // Освіта України. 2002. - 23 квіт. (№ 33). - С. 4-6.

13. Національна доповідь про стан і перспективи розвитку освіти в Україні / Нац. акад. пед. наук України ; [редкол.: В. Г. Кремень (голова), В. І. Луговий (заст. голови), О. Я. Савченко (заст. голови)] ; за заг. ред. В. Г. Кременя. - Київ : Пе- дагогічна думка, 2016. - 448 с. - Бібліогр.: с. 21. - (До 25річчя незалежності України). - С. 55.

14. Постанова Загальних зборів НАПН України «Проблеми модернізації змісту освіти в умовах реформування української школи» № 1-1/2-8 від 16 листопада 2018 р. - С. 2.

15. Про Національну стратегію розвитку освіти в Україні на період до 2021 року : указ Президента України від 25 черв. 2013 р. № 344/2013 // Практика упр. закл. освіти. - 2013. - № 8. - С. 54-67. - Національна стратегія... додається.

16. Про схвалення Концепції Державної цільової соціальної програми «Школа майбутнього» на 2007-2010 рр. : розпорядж. Кабінету Міністрів України від 13 квіт. 2007 р. № 160-р // Практика упр. закл. освіти. - 2007. - № 12. - С. 82-85. Концепція... додається.

17. Програма розвитку народної освіти Української РСР на перехідний період (1991-1995рр.) : затв. рішенням колегії М-ва нар. освіти УРСР від 19.06.1991 р., протокол № 6/37 // Інформ. зб. М-ва нар. освіти Укр. РСР. - 1991. - № 15/16. C. 4-36.

18. Реформування освіти в Україні: державно-управлінський аспект : навч.-наук. вид. / [Н. Г. Протасова, В. І. Луговий, Ю. О. Молчанова та ін.] ; за заг. ред. Н. Г. Протасової. - Київ ; Львів : НАДУ, 2012. - 456 с.

19. Савченко О.Я. Зміст шкільної освіти на рубежі століть / Савченко О.Я.//Освіта України.-2000.-12 квітня (№ 15).-С.4.

20. Сухомлинська О. В. Програми національного виховання в умовах освітніх цивілізаційних змін / Ольга Сухомлинська // Шлях освіти. - 2010. - № 4. - С. 4-8.

21. Berezivska L. D. Secondary education reform in Ukraine: concepts and drafts (1988-1991) / L. D. Berezivska // Science and Education a New Dimension. Pedagogy and Psychology (Budapest), VI (63), Issue: 153, 2018. - P. 7-10.

\section{REFERENCES}

1. Berezivska, L.D. School reform in Ukraine as a transition period to personality-oriented educational paradigm: the early 1990s // Pedagogical and Psychological Sciences of Ukraine : collected scientific papers. Kyiv : Pedahohichna Dumka Publishing House, 2012. Vol. 2. General Pedagogy and Philosophy of Education. P. 180-190.

2. Bidenko, N. Secondary education development in the independent Ukraine // Research Records. Historical Sciences Series. Kirovohrad: Kirovohradskyi Derzhavnyi Pedahohichnyi Universytet imeni Volodymyra Vynnychenka Publishing House, 2009. Issue 12. P. 213-225.

3. Halakh, V.V. The peculiarities of secondary education reform in the independent Ukraine // Taurida Education Bulletin, 2014. no. 4. P. 274-281.

4. State National Osvita (Education) Programme (Ukraine of the 21 century) : approved by the Decree by the Cabinet of Ministers of Ukraine on 3 November 1993 (No. 896) // Education, 1993. December (no. 44/46). P. 2-15.

5. Kasianov, H. Education system in Ukraine in 1990 - 2014: analytical review. Kyiv: TAKSON Publishing House, 2015. 52 p.

6. The Project of the Twelve-year Secondary Education Concept // Information Collected Papers by the Ministry of Education and Science of Ukraine, 2000. no. 21. P. 10-31.

7. The New Ukrainian School Concept of Public Policy in the Field of Secondary Education for 2016 - 2029 : approved by the Ordinance of the Cabinet of Ministers of Ukraine on 14 December 2016 (No. 988-p) // Ukrainian Lawmaking [Online]. Verkhovna Rada of Ukraine. Kyiv, 2016. Available from: http://zakon2.rada. gov.ua/laws/show/988-2016-\%D1\%80 [Accessed 17/08/18].

8. The project of the concept of secondary national school of Ukraine / The Ministry of National Education of the Ukrainian SSR and Research Institute of Pedagogy of the Ukrainian SSR // Soviet Education, 1990. 14 August (no. 65). P. 1-3.

9. The conception of formation of the system of secondary education institutions for the development of creative personality // Information Collected Papers by the Ministry of Education and Science of Ukraine, 1996. no. 17/18. P. 48-64.

10. Krasniakov. Y.V. Prospects of educational lawmaking in Ukraine // Public Administration : Theory and Practice : Electronic Scientific Professional Publication [Online]. National
Academy for Public Administration under the President of Ukraine. Kyiv, 2009. No. 9. Available from: http://academy.gov.ua/ej/ej10/doc_pdf/Krasniakov.pdf [Accessed 19/12/18].

11. Kremen, V.H. Education and science of Ukraine; ways for modernisation (facts, thoughts, prospects). Kyiv: Hramota Publishing House, 2003. 216 p.

12. The national doctrine of the development of education : approved by the President's Decree on 17 April 2002 (No. 347) // Education of Ukraine, 2002. 23 April (no. 33). P. 4-6.

13. The national report on the state and prospects of the development of education in Ukraine / The National Academy of Educational Sciences of Ukraine. Kyiv : Pedahohichna Dumka Publishing House, 2016. 448 p.

14. The decree of the NAES of Ukraine general meeting titled 'The problems of education content modernisation in the context of Ukrainian school reform' (No. 1-1/2-8, issued on 16 November 2018). P. 2.

15. On the national strategy of the development of education in Ukraine for 2013 - 2021 : approved by the President's Decree on 25 June 2013 (No. 344/2013) // Practice for Managing Educational Institutions, 2013. no. 8. P. 54-67.

16. On the approval of the concept of the state School of the Future special purpose social programme for 2007 - 2010 : approved by the ordinance of the Cabinet of Ministers of Ukraine on 13 April 2007 (No. 160-p) // Practice for Managing Educational Institutions, 2007. no. 12. P. 82-85.

17. The programme for the development of public education in the Ukrainian SSR for the transition period $(1991$ - 1995) : approved by the resolution of the ministry board on 19 June 1991 (Minutes No. 6/37) // Information Collected Papers by the Ministry of Public Education of the Ukrainian SSR, 1991. no. 15/16. P. 4-36.

18. Education reform in Ukraine : public and administrative aspects / ed. by Protasova N.H. Kyiv, Lviv : NADU Publishing House, 2012. 456 p.

19. Savchenko, O.Y. School education content at the turn of the century // Education of Ukraine, 2000. 12 April (no. 15). P. 4.

20. Sukhomlynska, O.V. The programme of national education under conditions of educational civilisational changes // Course 